Journal: Language Development Center

Vol. 1 No. 2, 2021, 12

\title{
SAFAR BATH IN THE VALUE PERSPECTIVE OF ISLAMIC EDUCATION IN THE ATINGGOLA COMMUNITY
}

\author{
${ }^{1}$ Nursidik I. Mohamad, ${ }^{2}$ Ibnu Rawandhy N. Hula \\ Email: ${ }^{1}$ nursidikimohamad2@gmail.com Coauthor: 2 ibnurawandi@iaingorontalo.ac.id \\ ${ }^{1}$ Jurusan Pendidikan Agama Islam, ${ }^{2}$ IAIN Sultan Amai Gorontalo
}

Article Info

Received:

03 December 2021

Accepted:

19 December 2021

Published:

13 January 2022

https://orcid.org/ 0000-0003-2569-3571

Key Word

\begin{abstract}
The purpose of this research is to find out; The value of Islamic education and traditional values contained in the Mandi Safardi procession, Jin City Village, Atinggola District, North Gorontalo Regency.

The method used is a qualitative method, the data is obtained through observation, interviews, and documentation. The data were then analyzed using reduction, display, and verification techniques, while the validity of the data was obtained by using triangulation techniques with methods and sources.

The results of this study indicate that the Safar Bathing Tradition is believed to have existed since their ancestors first occupied the Jin City Village area. The Safar Bathing tradition carried out by the Jin City Village community contains Islamic educational values, namely: Worship Values, Moral Values, Moral Values, and Aqidah Values, 4) The Safar Bathing Tradition is maintained and passed down from generation to generation by the Jin City Village community. can be seen as an expressive symbol of the Jin City Village community Inspired by constitutive (religious) symbols that have a corelative-integrative and dynamic relationship Suggestions from this research include; The Mandi Safar tradition as an ancestral cultural heritage should continue to be preserved for future generations by not eliminating the local Indonesian religious and cultural values contained in it as a medium for introducing ancestral traditions that are full of moral and religious values without ignoring the shari'ah. Islam in practice
\end{abstract} Safar Bath, V alue Perspective; Islamic Education; Atinggola.

\section{ABSTRAK}

Tujuan penelitian adalah untuk mengetahui; Nilai pendidikan Islam dan nilai Adat yang terkandung dalam prosesi Mandi Safardi Desa Kota Jin Kecamatan Atinggola Kabupaten GorontaloUtara. Metode yang digunakan adalah metode kualitatif, data diperoleh melalui observasi, wawancara dan dokumentasi. Data selanjutnya dianalisa dengan teknik reduksi, display dan verifikasi sedangkan keabsahan data diperoleh dengan teknik triangulasi dengan metode dan sumber. Hasil penelitian ini menunjukan Tradisi Mandi Safar diyakini telah ada sejak nenek moyang mereka pertama kali menempati wilayah Desa Kota Jin. Tradisi Mandi Safar yang dilakukan oleh masyarakat Desa Kota Jin, mengandung nilai pendidikan Islam, yaitu: Nilai Ibadah, Nilai Moral, Nilai Akhlak, dan Nilai Aqidah, 

berikutnya oleh masyarakat Desa Kota Jin dapat dipandang sebagai sebuah simbol ekspresif masyarakat Desa Kota Jin yang Diilhami oleh simbol konstitutif (agama) yang memiliki hubungan corelative-integratif dan dinamis

Saran dari penelitian ini mencakup; tradisi Mandi Safar sebagai warisan budaya nenek moyang hendaknya terus dilestarikan bagi generasi-generasi berikutnya dengan tidak menghilangkan nilai-nilai agama dan budaya lokal Indonesia yang ada di dalamnya sebagai sebuah media memperkenalkan tradisi nenek moyang yang sarat dengan nilai moral dan agama tanpa mengabaikan syari'at Islam dalam pelaksanaannya.

Mandi Safar, Nilai Pendidikan Islam, Nilai Adat

\section{PENDAHULUAN}

Indonesia as an archipelagic country has a variety of different traditions within a certain region and ethnic groups spread throughout Indonesia, including the people who inhabit the island of Lombok, West Nusa Tenggara. Tradition as stated by Funk and Wagnalls as quoted by Muhaimin is defined as knowledge, doctrine, habits, practices, etc. ${ }^{1}$

Islamic traditions that exist in Indonesia cannot be separated from the historical background of the presence of Islam in Indonesia which spread through da'wah and trade activities that occurred between trading ports in Indonesia and Arab, Gujarat, and Persian traders since the beginning of the arrival of Islam in the 7 th century AD. until the 17 th century AD Islam had spread and evenly throughout Indonesia by peaceful means through a touch of local Indonesian culture so that Islam could develop in almost all parts of Indonesia. The spread of Islamic teachings without eliminating local culture and traditions in Indonesia which was obtained from the teachings of the Hindu-Buddhist religion that had already existed and was embraced by the population gave birth to various types of different religious traditions in each region in Indonesia. ${ }^{2}$

In Islam, the tradition is known as the word urf which etymologically means something that is considered good and accepted by common sense. Al-Urf in terminology can be defined as something that is believed by the majority of people, either in the form of words or actions that have been repeated so that it is embedded in the soul and accepted by the mind. ${ }^{3}$ The Islamic traditions found in Indonesia, especially the traditions carried out by the Gorontalo people are the result of the process of Islamic development in regulating its adherents in carrying out daily activities and interactions. Islamic traditions tend to provide relief and convenience so that they do not force Muslims beyond their capabilities. ${ }^{4}$ The people of Gorontalo, the indigenous tribes who inhabit the island of Gorontalo highly uphold the traditions and customs passed down by their ancestors from generation to generation, so it is not

\footnotetext{
${ }^{1}$ Endang Fatmawati, "Strategies to grow a proud attitude towards indonesian cultural diversity", Linguistics and Culture Review 5, عدد August (2021): 810-820.

2 Ibnu Rawandhy, N Hula, g Ana Mariana, "The Beati Tradition in North Gorontalo District ( Ethnographic Study of Processions and Verbal Meanings of Tuja 'i) Tradisi Beati di Kabupaten Gorontalo Utara ( Studi Etnografi terhadap Prosesi dan Makna Verbal Tuja' i )" 20, 315-295: عدد 1 (2020).

${ }^{3}$ Renny Oktafia و Imron Mawardi, "Islamic Values in The Tradition of Samin Community at East Java", QIJIS (Qudus International Journal of Islamic Studies) 5, عدد 1 (2017): 97.

${ }^{4}$ Robert J. Lieber و Ruth E. Weisberg, "Globalization, culture, and identities in crisis", International Journal of Politics, Culture and Society 16, 296-273: عدد 2 (2002).
} 
surprising that the people of Gorontalo have various unique and interesting traditions that distinguish them from other tribes in Indonesia. Indonesia.

Among the traditions possessed by the Gorontalo community is the "Safar Bathing" tradition carried out by the Gorontalo people who inhabit Atinggola District, North Gorontalo Regency. Jin City Village which consists of the Jin City tourist area (Minanga Beach) is one of the villages in North Gorontalo Regency which routinely carries out Safar Bathing activities every year. This Safar Bathing tradition is an inherited tradition from the ancestors of the original inhabitants of Jin City Village who are part of the Gorontalo tribe.

Based on the results of initial observations at the research site, the researchers found that the Safar Bathing tradition is routinely held by the community on the last week of the Safar month every year. The Safar Bathing tradition was attended and followed by hundreds or even thousands of people from all the residents of Jin City Village and the surrounding Village Communities and even many residents who came from outside Jin City Village without any certain limitations (age, social strata, economy, and others). This tradition is carried out in several stages, starting from preparation, implementation and closing. At the preparatory stage, the community deliberates and together prepares everything needed in the implementation of the bathing safar tradition, starting from preparing the theme of the activity, equipment, and determining the location of the event. ${ }^{5}$

Each stage and series of events carried out in the implementation of the Safar Bath contains its own meaning and value for the people of Jin City Village. For example, in the preparatory stage, there is the value of deliberation and consensus, collective prayer symbolizes the value of faith, piety, and a request for help to Allah SWT, and bathing together as the climax event symbolizes self-purification from all despicable morals. ${ }^{6}$

The implementation of the Mandi Safar tradition carried out by the Jin City Village community which is full of meaning and value is used as a means of education by the community for the younger generation of Jin City Village in preparing a generation that understands religion, tradition and loves the environment.

The people of Jin City Village, Atinggola District, as a community whose majority of the population embraces Islam are still trying to maintain Islamic traditions that have existed for a long time such as the Mandi Safar tradition. The Mandi Safar tradition is used as an educational tool for the younger generation to introduce them to the values of Islamic education so that the younger generation does not lose their identity in the midst of an increasingly global era and in the midst of the ravages of outside (Western) culture that cannot be separated from the City Village. Jin as a mainstay tourist destination in North Gorontalo Regency.

Based on the description above, the researchers conducted a study to find the value of Islamic education and traditional values in the Mandi Safar tradition carried out by the people of Jin City Village, Atinggola District, North Gorontalo Regency with the title Mandi Safar research in the Perspective of Islamic Educational Values and Customary Values in Society. Atinggola.

\footnotetext{
${ }^{5}$ Irmawati Sagala, "Extension of Religious Ritual Functions in Development Process: Study of Mandi Safar in Air Hitam Ocean Indonesia", IOP Conference Series: Earth and Environmental Science 156, 1 (2018).

${ }^{6}$ S. Singaravelu, "The Malay-Tamil Cultural Contacts with Special Reference to the Festival of 'Mandi Safar'", Asian Folklore Studies 45, عدد 1 (1986): 67.
} 


\section{METODE}

This study uses a qualitative approach. ${ }^{7}$ Data obtained in the field is data information or information related to the problem to be studied so that the data is described not in statistical figures. This research was conducted in Kota Jin Village, Atinggola District, North Gorontalo Regency for approximately 3 (three) months.

Primary data sources are sources that directly provide data to researchers. Primary sources were determined by purposive sampling, through collecting data from informants including religious leaders, traditional stakeholders, and community leaders in Atinggola sub-district. While secondary data sources are sources that do not directly provide data, which in this case is through document records related to the problems studied, which function as complementary primary data.

Data were collected by participating in observational techniques, in-depth interviews, and document analysis. The techniques used, 1) Participatory Observation, 2) Interviews, and 3) Documentation. ${ }^{8}$ The analytical model used in this study is the interactive model developed by Miles and Huberman which begins with data collection, data reduction, data presentation, and conclusion drawing/verification. The validity of the data was obtained by two techniques, namely focused observation and triangulation. ${ }^{9}$

\section{HASIL PEMBAHASAN}

\section{a. Educational Value}

In the context of Islam, linguistically there are three words used. The three words, namely: AtTarbiyah, At-Ta'lim, and At-Ta'dib. These three words have interrelated meanings that are suitable for the meaning of education in Islam. These three meanings contain very deep meanings, concerning humans and society, and the environment in relation to God are related to one another. Meanwhile, in terms of Islamic education is education according to Islam or Islamic education, namely education that is understood and developed from the teachings and fundamental values contained in its basic sources, namely the Qur'an and Sunnah. ${ }^{10}$

Based on the analysis that the researchers conducted on the results of observations, interviews, and documentation at the research site on the origins and implementation of the Safar Bathing tradition carried out by the Jinn City Village community, the researcher can explain that the implementation of the Safar Bathing tradition contains the values of Islamic education as follows.

\section{The Value of Worship}

In terms of the aims and objectives of the Islamic jurisprudence, fiqh scholars divide it into three types, namely: 1) worship of mahdah, 2) worship of gair mahdah and 3) worship of zi al-wajhain.

1) Worship Mahdah is worship that contains a relationship with Allah swt solely, namely a vertical relationship. This worship is only limited to special worship. The characteristics of mahdah

\footnotetext{
${ }^{7}$ Gamze Arabelen و Hasan Tolga Kaya, "Assessment of logistics service quality dimensions: a qualitative approach", Journal of Shipping and Trade 6, 13-1 عدد 1 (2021), https://doi.org/10.1186/s41072-021-00095-1.

8 Musdalifah Musdalifah وآخ و., "Building the Management System: Designs on the use of Blended Learning Environment", Journal of Physics: Conference Series 1783, 1 عدد (2021).

${ }^{9}$ Helen Noble و Roberta Heale, "Triangulation in research, with examples", Evidence-Based Nursing 22, 3 (2019) 3 68-67.

${ }^{10}$ Omar Farahat, "Moral Value and Commercial Gain: Three Classical Islamic Approaches", Journal of Arabic and Islamic Studies, Forthcoming (2021).
} 
worship are that all the provisions and rules for its implementation have been determined in detail through the explanations of the Qur'an and hadith. Mahdah worship is carried out solely with the aim of getting closer to Allah swt. For example ablution, tayammum, bathing hadats, prayer, shiyam (fasting), hajj, umrah and tajhiz al-janazah.

2) Ghair mahdah worship is worship that is not only related to the relationship with Allah swt, but also relates to fellow creatures (habl min Allah wa habl mi an-nas), in addition to the vertical relationship there is also a horizontal relationship. The relationship between these creatures is not only limited to the relationship between humans, but also the relationship between humans and their environment.

3) Worship zi al-wajhain is worship that has two characteristics at once, namely mahdah and ghairu mahdah. The point is that some of the purposes and objectives of the Shari'a can be known and some cannot be known, such as marriage and iddah.

The implementation of the Safar Bathing tradition ${ }^{11}$ carried out by the village community of the jin city on the last Wednesday of the month of Safar in the Hijriyah calendar every year is clearly a form of mutual assistance carried out by the village community of the jinn city. The value of mutual assistance is seen in every series of Mandi Safar tradition events that are carried out where all elements of society work hand in hand in preparing for the implementation of the event.

In the Mandi Safar tradition, a communal meal is also held which serves various types of food which are not only allowed to be eaten by all residents of the Jinn City Village but can also be eaten by all those present in the implementation of the Safar Mandi tradition regardless of social status and age. They help ease the burden of others in meeting their daily needs, especially in relation to meeting food needs, helping each other in the construction of places of worship, and so on.

This Safar bathing activity is also useful in instilling an attitude of cooperation between communities in doing everything, wherein the implementation of this tradition the Jinn City Village community always involves all elements of society in the success of the Safar Bathing tradition which is routinely carried out every year. The value of this help can also be seen from how the people of Jin City Village together make all the equipment needed in the implementation of this tradition.

In Arabic, helping has an equivalent to the word ta'awun. Ta'awun in Islam can be seen as an attitude of togetherness based on feelings of belonging and mutual need between one party and another. Ta'awun can give birth to a harmonious life in society because all components in society can work together in completing various kinds of activities or work. With this attitude of help, every individual in society will feel helped and can give birth to empathy in each member of the community. For this reason, Ta'awu in this study is part of the Value of Worship which in developing the value of worship is to invite people to work together to achieve a good goal. ${ }^{12}$

\section{b. Moral Value}

The moral values contained in Islamic values, ${ }^{13}$ of course, can be found and can be seen with the postulates that can be understood and developed, and empowered by humans themselves, in this study the intended moral value is the value of brotherhood in the Mandi Safar tradition which is reflected in the absence of specialization of participants who may follow the Safar Bathing tradition. All people are allowed to follow this tradition, even people from outside Jin City Village, regardless of social status,

\footnotetext{
${ }^{11}$ Romi Aqmal, Ferri Yonantha, g Rajabbul Amin, "Islamic Perspective on the Tradition of “ Mandi Safar " in the Long Tomb of Pengujan Village" 2, 210-201: عدد 2 (2021).

12 Peter. O. O. Ottuh و Mary O. Jemegbe, "Communication in Religion and Its Integrative Implications for Society", PINISI Discretion Review 4, 1 : عد 1 (2020).

13 Syahraini Tambak وآخ., "Internalization of Islamic Values in Developing Students' Actual Morals", JPI (Jurnal Pendidikan Indonesia) 10, عدد 4 (2021): 697-
} 
age limit or background of the participants. All of them happily and joyfully participated in the whole series of events in the Safar Bathing tradition. They are all viewed and have the same position as servants of Allah SWT and have the same goal, namely hoping to avoid all calamities and diseases.

In Islam, brotherhood is known as ukhuwah. Ukuhuwah basically means equality and harmony in many ways. Hence equality in lineage and equality in character also leads to brotherhood. The meaning of ukhuwah as stated has the consequence that every individual who has similarities and harmony (both similarities in descent and nature) with other individuals is said to be brother. Furthermore, Quraish Shihab said that the second meaning of ukhuwah (similarity in nature) resulted in humans who have extravagant and extravagant traits being said to be brothers of Satan. ${ }^{14}$

\section{c. Akhlak Values}

The akhlak values that are relevant to the values of Islamic education are closely related to the existence of akhlaq al-karimah which includes morality to Allah and morality to oneself as well as morality between fellow humans which reflects the elegance of human morality in the family, society and nation. In this study, the moral values that are relevant in the tradition of bathing safar in the village of the city of the genie are deliberation for consensus.

Deliberations for consensus in the implementation of the Safar Bathing tradition carried out by the Jin City Village community are seen in the deliberation carried out before the Safar Bathing tradition is carried out. This activity is always started by the people of Jin City Village with a deliberation process. This annual tradition which is inherited from their ancestors is seen as a tradition that must be carried out and passed on from one generation to the next. Because this tradition is very important for the community, before its implementation a village meeting is always held to discuss various kinds of preparations and a series of activities in the implementation of the Safar Bathing tradition later.

\section{d. Value of Aqidah}

The values of aqidah possessed by Islamic education are closely related to human activities in carrying out their lives in worshiping themselves solely for Allah SWT, therefore Islam teaches that life and all aspects of life must be intended as devotion to Allah.

In the meaning of the research on the safar bathing tradition, the value of Aqidah is part of gratitude for the activities of the safar mandis tradition. So that it is a form of community gratitude for all kinds of favors that have been given by Allah SWT both in the form of health and natural wealth owned by the people of Jin City Village. As a form of their gratitude at the time of the Safar Bathing tradition, the entire community of Jin City Village offered dhikr and prayers together which they ended with sharing activities with others by holding a banquet that could be enjoyed by everyone who was present in the celebration of the Safar Bathing tradition. except for residents who come from outside the Jin City Village who work in the Jin City Village or just come to witness the implementation of the Safar Bathing tradition. The essence of gratitude is the appearance of favors, while the essence of disbelief is to hide them. Showing a favor means, among other things, using it in the place and in accordance with what the giver wants, also mentioning the favor and giving it verbally.

\section{d. Traditional Value ${ }^{15}$}

The tradition carried out in Atinggola, precisely in the village of Jin City, Atinggola District, Kabupaten, North Gorontalo, contains traditional values and this meaning requirement is embodied at

\footnotetext{
${ }^{14}$ H. Rachmah وآخ وآخ and Environmental Science 747, 8-1: عدد 1 (2021).

15 Andreas Maercker وآخ., "Traditional versus modern values, self-perceived interpersonal factors, and posttraumatic stress in Chinese and German crime victims", Psychology and Psychotherapy: Theory, Research and Practice 82, 232-219 :2009) 2 (2019.
} 
the stage of carrying out a safar bath. For this reason, the researcher will describe the traditional values contained in the process of carrying out a safari bath

1. The value of Molo'opu

At the implementation stage, an imam and local customary head pick up the governor/mayor to be invited to sit in the provided place to witness and at the same time start the safar bathing event. ${ }^{16}$ At this stage, the customary value in question is respect for the regional leader / ulil amri. For this reason, through the moloopu process, it gives a message to the Atinggola community that the value of respect for the leader/ulil amri is important for the realization of mutual respect between the community and the leader. ${ }^{17}$

\section{The value of Mopoma'lumu}

At this stage the customary holder will notify the regional leader that the event will start soon, ${ }^{18}$ then the regional leader will give a signal to start immediately. At this stage, the customary values taken are the norm values for telling each other that it is etiquette to tell others or to the leader.

\section{Mopoyilihu value}

Mopoyilihu or drifting leaves is a process in which traditional stakeholders wash away leaves on which prayers have been written in the form of prayers of salvation. In this process, the value that is meant is that along with the drifting of the leaves with the hope that all dangers of all diseases will be washed away with the leaves. What is not important is that in the mohilihu process, the message that contains traditional values is to wash away all forms of liver disease such as envy, jealousy, pride, and many other liver diseases. ${ }^{19}$

\section{PENUTUP}

The Safar Bathing tradition carried out by the Jin City Village community comes from the ancestors of the Jin City Village community. The Safar Bathing tradition is believed to have existed for hundreds of years when their ancestors first occupied the Jin Town Village area. The implementation of the Mandi Safar tradition by the Jin City Village community is carried out in several stages, namely: preparation stage, implementation stage, and closing.

The Safar Bathing tradition carried out by the Jin City Village community contains the values of Islamic education, namely: Worship Values, Moral Values, Moral Values, and Aqidah Values. The Bathing Safar tradition is a tradition of the Islamic community whose law is still being debated. But behind the debate, the Mandi Safar tradition contains the value of Islamic education that must be maintained. The Mandi Safar tradition as a tradition that is maintained and passed down from generation to generation by the people of Jin City Village can be seen as an expressive symbol of the Jin City Village community inspired by constitutive (religious) symbols that have a correlative-integrative and dynamic relationship.

\footnotetext{
16 Rachmi Laya, "Formula in Tuja'i Molo'opu Custom Speech Procession of Leaders Acceptance in Gorontalo Community", Journal of Humanities and Social Sciences Studies 3, 11-01: عدد 6 (2021).

17 Kasim Yahiji Rahmawati, "MOLO', OPU TRADITION IN TERM OF GORONTALO ' S ETNHIC LEADERSHIP" 74-59:(د.).

${ }^{18}$ Ibnu Rawandhy N Hula و Ana Mariana, "Tradisi Beati di Kabupaten Gorontalo Utara", Al-Ulum 20, عدد 2 (2020) $315-295$.

${ }^{19}$ Sofyan A P Kau g Kasim Yahiji, Akulturasi Islam dan Budaya Lokal: Studi Islam tentang Ritus-Ritus Kehidupan dalam Tradisi Lokal Muslim Gorontalo, 1 مج. (Inteligensia Media, 2018).
} 


\section{DAFTAR PUSTAKA}

Aqmal, Romi, Ferri Yonantha, g Rajabbul Amin. "Islamic Perspective on the Tradition of " Mandi Safar " in the Long Tomb of Pengujan Village" 2, no. 2 (2021): 201-210.

Arabelen, Gamze, و Hasan Tolga Kaya. "Assessment of logistics service quality dimensions: a qualitative approach". Journal of Shipping and Trade 6, no. 1 (2021): 1-13. https://doi.org/10.1186/s41072-02100095-1.

Farahat, Omar. "Moral Value and Commercial Gain: Three Classical Islamic Approaches". Journal of Arabic and Islamic Studies, Forthcoming (2021).

Fatmawati, Endang. "Strategies to grow a proud attitude towards indonesian cultural diversity". Linguistics and Culture Review 5, no. August (2021): 810-820.

Hula, Ibnu Rawandhy N, g Ana Mariana. "Tradisi Beati di Kabupaten Gorontalo Utara". Al-Ulum 20, no. 2 (2020): 295-315.

Kau, Sofyan A P, g Kasim Yahiji. Akulturasi Islam dan Budaya Lokal: Studi Islam tentang Ritus-Ritus Kebidupan dalam Tradisi Lokal Muslim Gorontalo. 1 . Inteligensia Media, 2018.

Laya, Rachmi. "Formula in Tuja'i Molo'opu Custom Speech Procession of Leaders Acceptance in Gorontalo Community". Journal of Humanities and Social Sciences Studies 3, no. 6 (2021): 01-11.

Lieber, Robert J., g Ruth E. Weisberg. "Globalization, culture, and identities in crisis". International Journal of Politics, Culture and Society 16, no. 2 (2002): 273-296.

Maercker, Andreas, Changiz Mohiyeddini, Mario Müller, Wei Xie, Zhi Hui Yang, Jiangping Wang, g Julia Müller. "Traditional versus modern values, self-perceived interpersonal factors, and posttraumatic stress in Chinese and German crime victims". Psychology and Psychotherapy: Theory, Research and Practice 82, no. 2 (2009): 219-232.

Musdalifah, Musdalifah, Baharuddin Baharuddin, Umiyati Jabri, Elihami Elihami, g Mustakim Mustakim. "Building the Management System: Designs on the use of Blended Learning Environment". Journal of Physics: Conference Series 1783, no. 1 (2021).

Noble, Helen, g Roberta Heale. "Triangulation in research, with examples". Evidence-Based Nursing 22, no. 3 (2019): 67-68.

Oktafia, Renny, g Imron Mawardi. "Islamic Values in The Tradition of Samin Community at East Java". QIJIS (Qudus International Journal of Islamic Studies) 5, no. 1 (2017): 97.

Ottuh, Peter. O. O., و Mary O. Jemegbe. "Communication in Religion and Its Integrative Implications for Society". PINISI Discretion Review 4, no. 1 (2020): 1.

Rachmah, H., A. M. Tsaury, Khambali, Enoh, g E. Surbiantoro. "Tabdzir prohibition education in overcoming consumptive behavior". IOP Conference Series: Earth and Environmental Science 747, no. 1 (2021): 1-8.

Rahmawati, Kasim Yahiji. "MOLO' OPU TRADITION IN TERM OF GORONTALO' S ETNHIC LEADERSHIP" 74-59:(د.). 
Rawandhy, Ibnu, N Hula, g Ana Mariana. "The Beati Tradition in North Gorontalo District ( Ethnographic Study of Processions and Verbal Meanings of Tuja' i ) Tradisi Beati di Kabupaten Gorontalo Utara ( Studi Etnografi terhadap Prosesi dan Makna Verbal Tuja' i )" 20, no. 1 (2020): $295-315$.

Sagala, Irmawati. "Extension of Religious Ritual Functions in Development Process: Study of Mandi Safar in Air Hitam Ocean Indonesia". IOP Conference Series: Earth and Environmental Science 156, no. 1 (2018).

Singaravelu, S. "The Malay-Tamil Cultural Contacts with Special Reference to the Festival of 'Mandi Safar"'. Asian Folklore Studies 45, no. 1 (1986): 67.

Tambak, Syahraini, Hamzah Hamzah, Desi Sukenti, g Mashitah Sabdin. "Internalization of Islamic Values in Developing Students' Actual Morals". JPI (Jurnal Pendidikan Indonesia) 10, no. 4 (2021): 697-709. 